\title{
IMPLEMENTASI MANAJEMEN PEMASARAN JASA PENDIDIKAN DALAM MENINGKATKAN KEPUASAN PELANGGAN DI MADRASAH ALIYAH TERPADU (MAT) DARUL FALLAH BOGOR
}

\author{
Sarifudin $^{1}$, Rehendra Maya ${ }^{2}$ \\ ${ }^{1}$ Prodi Manajemen Pendidikan Islam STAI Al Hidayah Bogor \\ ${ }^{2}$ Prodi Pendidikan Islam STAI Al Hidayah Bogor \\ email: sarifudin1182@gmail.com \\ e-mail: rahendra.maya76@gmail.com
}

Received: 09/07/2019, Accepted: 25/07/2019, Published: 31/07/2019

\begin{abstract}
The management of marketing education services will be good if done correctly and professionally. The aim of the marketing management of education services is to facilitate the institution in marketing its educational services to the community. The purpose of this study is to be able to find out how the implementation of the mix strategy in the marketing management of education services in the Darul Fallah Integrated Aliyah Madrasah (MAT) Bogor. This scientific research uses qualitative methods by collecting data from field observation activities, interviews with relevant sources, and taking documentation from the research site. The marketing mix of education services in MAT Darul Fallah Bogor includes: (1) Product strategy; (2) Price Strategy; (3) Place Strategy (location); (4) Promotion Strategy; (5) People Strategy; (6) Physical Evendece Strategy; and (7) Process Strategy. In addition, this study also discusses the development of marketing education services in MAT Darul Fallah Bogor from year to year and various kinds of educational services products offered so that consumers are more interested in seeing firsthand the advantages of this school.
\end{abstract}

Keywords: management, marketing, education services, satisfaction.

\begin{abstract}
ABSTRAK
Pengelolaan pemasaran jasa pendidikan akan baik jika dilakukan dengan benar dan profesional. Tujuan dari manajemen pemasaran jasa pendidikan untuk memepermudah lembaga dalam memasarkan jasa pendidikannya kepada mayarakat. Tujuan penelitian ini yaitu agar dapat mengetahui bagaimana implementasi strategi bauran dalam manajemen pemasaran jasa pendidikan di Madrasah Aliyah Terpadu (MAT) Darul Fallah Bogor. Penelitian ilmiah ini menggunakan metode kualitatif dengan mengumpulkan data dari kegiatan observasi lapangan, wawancara terhadap sumber yang relevan, dan pengambilan dokumentasi dari tempat penelitian. Pelaksanaan bauran pemasaran jasa pendidikan di MAT Darul Fallah Bogor antara lain: (1) Strategi produk; (2) Strategi Price; (3) Strategi Place (lokasi); (4) Strategi Promotion; (5) Strategi People; (6) Strategi Physical Evendece; dan (7) Strategi Process. Selain itu penelitian ini juga membahas tentang perkembangan pemasaran jasa pendidikan di MAT Darul Fallah Bogor dari tahun ke tahun dan berbagai macam produk jasa pendidikan yang ditawarkan agar konsumen lebih tertarik untuk melihat secara langsung keunggulan dari sekolah ini.
\end{abstract}

Kata kunci: Manajemen, pemasaran, jasa pendidikan, kepuasan 


\section{PENDAHULUAN}

Pada era globalisasi sekarang seperti ini, dalam dunia pendidikan terjadinya persaingan antara satu lembaga dengan lembaga pendidikan lainnya, sehingga yang terjadi banyak lembaga pendidikan yang ditinggalkan oleh penggunanya dengan beberapa alasan. Oleh sebab itu, dibutuhkan suatu kemampuan pengolahan yang profesional agar bisa mempraktekkan dalam pengolahan pemasaran jasa pendidikan yang bertujuan untuk mempertahankan dan memenuhi kebutuhan konsumen serta meningkatkan tujuan dari lembaga pendidikan tersebut. Dewasa ini terjadi persaingan antara sekolah umum dengan madrasah (agama) terjadi sangat ketat. Sekolah yang berbasis umum sering membuka jurusan baru sehingga bisa menambah kelas lagi dan akhirnya semakain banyak kelas-kelas yang ada. Sedangkan sekolah yang berbasis agama (madrasah) kurang diketahui atau kurang peminat oleh sebagian masyarakat, sehingga yang terjadi masyarakat beranggapan bahwa sekolah madrasah merupakan sekolah kelas kedua yang kalah bersaing dengan sekolah umum, hanya dari sebagian kalangan masyarakat tertentu saja anaknya dimasukan ke sekolah madrasah.
Pada saat ini setiap bangsa berlombalomba untuk dapat meningkatkan kualitas masyarakatnya, karena dengan pendidikan dapat meningkatkan peradaban yang bersangkutan menjadi bangsa yang bermartabat (Sarifudin. 2019: 50). Oleh sebab itu, lembaga pendidikan hendaknya dapat meningkatkan kualitas dan mutu pendidikan lulusannya. Sehingga masayarakatpun selaku pengguna jasa pendidikan tersebut akan berfikir selektif dalam menentukan lembaga mana yang harus dipilih untuk putra-putrinya. Masayarakat sudah cerdas dalam memilih lembaga pendidikan, mereka akan memilih lembaga pendidikan yang menurut mereka terjangkau dan tetunya terbaik dan berkualitas. Oleh sebab itu hendaknya lembaga pendidikan harus bisa membuat inovasi yang baru demi memenuhi kebutuhan dari pengguna. Bila ada lembaga pendidikan yang tidak mengikuti keinginan dari pengguna maka secara otomatis lembaga pendidikan tersebut akan ditinggalkan oleh penggunanya.

Sekolah sebagai sebuah lembaga yang menawarkan produk dari jasa pendidikan yang mereka tawarkan kepada masyarakat harus bisa mengambil hati dan meyakinkan kepada masyarakat bahwa lembaga pendidikan yang dia 
kelola adalah lembaga pendidikan yang tepat. Oleh sebab itu, perlu adanya inisiatif dari sekolah mulai dari menganalisis segmentasi pasar, melakukan perencanaan, pelaksanaan yang baik, serta melakukan proses pengendalian dan evaluasi. Sebuah lembaga pendidikan hendaknya bisa merancang dan menetapkan strategistrategi bauran pemasaran apa yang kira mampu dapat meyakinkan pengguna jasa pendidikan, seperti merencanakan program-program kegiatan yaitu dengan menjabarkan visi dan misi lembaga pendidikan, serta melaksanakan rangkain kegiatan dari program-program yang direncanakan secara konsisten dan sistematis.

Dalam pengolahan manajemen pemasaran jasa pendidikan yang ditawarkan oleh lembaga pendidikan kepada masyarakat harus bisa meyakinkan masyarakat, sehingga yang terjadi minat masyarakat sebagai pengguna merasa tertarik dengan strategi yang ditawarkannya dan akhirnya masyarakat pun menyekolahkan anaknya ke lembaga pendidikan tersebut, pemasaran jasa pendidikan adalah menawarkan mutu layanan intektual secara menyeluruh dan komprehensip.

Inti dari konsep pemasaran jasa pendidikan adalah memuaskan konsumen atau pengguna jasa pendidikan, dalam hal ini peserta didik sebagai pengguna utama. Komponen-komponen pendidikan harus saling bekerjasama antara satu dengan yang lain komponen-komponen pendidikan tersebut seperti tujuan pendidikan, isi pendidikan, metode pendidikan, alat pendidikan, lingkingan pendidikan, pendidik, dan peserta didik (Ummu Kulsum, Sarifudin, Rahendra Maya, 2019: 154).

Pendidikan juga memerlukan strategi yang mantap dalam melaksanakan proses pendidikan dengan melihat situasi dan kondisi yang ada. Juga bagaimana agar dalam proses tersebut tidak ditemui hambatan serta gangguan baik internal maupun eksternal yang menyangkut kelembagaan atau lingkungan sekitarnya (Rahendra Maya, 2016: 1189)

Strategi dalam memasarkan produk lembaga pendidikan yang tepat adalah dengan menerapkan prinsip fokus bagaimana caranya agar masyarakat sebagai pengguna terpuaskan. Salah satu langka yang tepat adalah dengan memberikan kesan atau citra yang baik (positif) kepada masayarakat, maksud dari memberikan kesan (citra) adalah sebuah kesan positif yang diperoleh oleh masyarakat sesuai dengan pengetahuan, pemahaman, dan pengalaman seseorang tentang sesuatu lembaga pendidikan. 
Citra tersebut terbentuk dari bagaimana sebuah lembaga pendidikan menjalankan kegiatan operasional pendidikan. Citra yang baik yang ditimbul oleh sebuah organisasi akan berdampak baik bagi lembaga pendidikan tersebut, sedangkan sebaliknya citra yang jelek akan berdampak merugikan terhadap organisasi tersebut (Sutisna, 2003: 331).

Dalam hal ini, pelanggan (peserta didik) jasa pendidikan terbagi dalam dua jenis, yaitu pelanggan internal dan pelanggan eksternal. Yang dimaksud dengan pelanggan internal ini adalah terdiri atas dewan guru, pustakawan, laboran, teknisi dan tenaga administrasi dan tenaga kependidikan lainnya. Sedangkan yang dimaksud dengan pelanggan eksternal adalah terdiri dari pelanggan primer (peserta didik), pelanggan skunder (orang tua, pemerintah, dan masyarakat), pelanggan tersier (pemakai atau penerima dari lulusan, baik dari lembaga pendidikan yang lebih tinggi maupun dari dunia usaha) (Mujamil Qomar, 2007: 200).

Kegiatan pemasaran jasa pendidikan sangatlah urgen karena keberadaan konsumen (pengguna) sebagai urat nadi manajemen bisnis lembaga pendidikan. Oleh sebab itu, agar pengolahan manajemen pemasaran maka diperlukan adanya kebijakan-kebijakan yang dapat menyeimbangkan antara nilai mutu sekolah berbanding lurus dengan tuntutan dan harapan dari pengguna dalam hal ini adalah masyarakat. Seperti adanya suatu pengolahan terhadap kinerja guru, yaitu berupa kegiatan supervisi. Malalui pengawasan, sosialisasi, dan pelatihan guru diharapkan memiliki kompetensi sebagai pedoman dalam mengajar serta telah memiliki keterampilan-keterampilan dalam mengajar dan mendidik (Sarifudin, 2019: 51). Dalam tataran idealitaskonseptualitas maupun realitas historisimplementatifnya, guru dan murid sebagai komponen utama pendidikan harus memiliki karakter yang baik, artinya guru harus menjadi guru yang berkarakter dan murud harus menjadi murid yang berkarakter pula. Tidak hanya dengan bersandarkan kepada nilai umum yang berlaku universal (Rahendra Maya, 2017: 23). Lembaga pendidikan yang ada di Indonesia harus bekerja keras dalam melaksanakan total quality management (TQM), karena semua organisasi atau lembaga yang ingin mempertahankan keberhasilan harus berobsesi pada mutu (Husaini Usman, 2006: 460).

Dewasa ini tidak sedikit lembaga pendidikan yang ada di Indonesia melakukan pengembangkan mutu pendidikan, yaitu dengan menggabungkan kurikulum pendidikan 
pemerintah dengan kurikulum lembaga pendidikan itu sendiri. Yang pada intinya adalah untuk memajukan mutu pendidikan umat Islam. Hal ini sejalan dengan apa yang dikemukakan oleh Rahendra Maya dan Iko Lesmana, bahwa pendidikan itu sendiri mampu mengatasi kemunduran umat tersebut dan untuk kemudian memajukannya, yaitu memajukan keadaan umat Islam melalui kemajuan pendidikan Islam (Rehendra Maya dan Iko Lesmana. 2018: 293). Salah satu contoh sekolah yang eksis dalam pemasaran pendidikan Islam adalah Madrasah Aliyah Terpadu (MAT) Darul Fallah Bogor. Sekolah ini merupakan sekolah yang cukup lama berdiri yaitu pada tahun 1960. Sekolah ini banyak melahirkan banyak alumni yang tersebar di seluruh Indonesia. Berdasarkan pembahasan di atas, maka penulis sangat tertarik untuk mengkaji suatu penelitian tentang implementasi manajemen pemasaran jasa pendidikan di MAT Darul Fallah Bogor.

\section{TINJAUAN TEORITIS}

Proses kegiatan manajemen biasanya terdapat kegiatan perencanaan yang dilakukan di awal, selanjutnya adalah kegiatan pengorganisasian, kegiatan penggerakan masing-tugas tugas yang telah ditentukan, selanjutnya adalah kegiatan pengawasan atau pengontrolan, semua dari kegiatan tersebut diharapkan berjalan secara efektif dan efesien demi tercapainya tujuan yang diinginkan dengan memanfaatkan segalah sumber daya yang ada baik itu sumber daya manusia maupun sumber daya yang lainya. Pendapat George R. Terry sebagaimana yang dijelaskan oleh Mulyono, bahwa ada empat fungsi manajemen, yaitu pertama planning yang berarti kegiatan perencanaan, kedua organizing yang berarti pengorganisasian, ketiga actuating yang berarti penggerakan atau pengarahan, dan keempat controlling yang berarti pengendalian atau pengawasan. Semua istilah tersebut dalam ilmu manajemen disebut sebagai istilah POAC (Mulyono, 2008: 22-23).

Dalam bahasa Inggris istilah pemasaran bisa disebut sebagai marketing, kata marketing sendiri sudah diserap dalam bahasa Indonesia. Asal kata pemasaran adalah pasar yang berarti market (Buchari Alma, 2014:1). Kalimat marketing dijelasakan oleh Philip Kotler dan Amstrong dalam buku Manajemen Pemasaran dan Pemasaran Jasa yaitu marketing management dapat dirumuskan sebagai the analisis planing, implementation, and control program designed ocreate, build, and maintain beneficial exchanges with target buyers 
for the purpose of achieving organizational objectives. Maksud dari penjelasan di atas adalah sebuah proses kegiatan menganalisa obyek, selanjutnya merencanakan, mengimplementasikan atau melaksanakan perencanaan tersebut, dan mengawasi segalah bentuk program kegiatan yang telah ditentukan. Maksud dari semua kegiatan ini adalah untuk memperoleh tingkat pertukaran yang saling menguntungkan dengan pembeli (pengguna) dalam rangka mencapai tujuan organisasi yang bersangkutan (Buchari Alma, 2014: 130).

Kegiatan pemasaran dapat diartikan sebagai sebuah kegiatan sosial yang berupa kegiatan-kegiatan manajerial antara beberapa pihak baik itu individu maupun kelompok yang diharapkan mendapatkan kebutuhan atau keinginan dengan melalui pertukaran dengan pihak lain dan mengembangkan hubungan pertukaran saling menguntungkan antara pihak satu dengan lainnya. Perlu disadari bahwa proses kegiatan pemasaran biasanya dipengaruhi oleh beberapa faktor tertentu misal manajerial, budaya, politik, dan sosial. Akibat dari beberapa pengaruh yang ada maka individu atau pengguna mendapatkan kebutuhan dan keinginan mereka dengan mencipkan, menawarkan, dan bertukar sesuatu yang bernilai satu sama lain (Ara Hidayat dan
Imam Machali, 2012: 223-224). Maka dari itu, dapat ditarik kesimpulan bahwa kegiatan pemasaran adalah kegiatan sosial (bersama-sama) dan kegiatan manajerial dimana terdiri dari individu dan kelompok yang keduanya saling mendapatkan kebutuhan dan keinginan masing-masing yaitu dengan menciptakan jasa, kemudian menawarkan, dan setelah itu bertukar sesuatu yang memiliki nilai satu sama lain yang saling menguntungkan. Tujuan dari proses pemasaran pada intinya adalah tidak hanya berfungsi untuk mendistribusikan produk atau jasa tapi melayani pengguna atau pelanggan demi mendapatkan kepuasan dari jasa yang ditawarkannya.

Lembaga pendidikan adalah sebuah lembaga yang termasuk ke dalam lembaga non profit organization. Sedangkan istilah komersial dapat diartikan dengan kegiatan mencari laba atau keuntungan, atau bisa disebut sebagai konsep negatif yang berarti "dikomersilkan", sehingga bisa ditafsirkan dengan ada uang ada layanan, pokoknya segala kegiatan harus menghadirkan keuntungan yang menghasilkan uang.

Pemasaran jasa pendidikan dapat direalisasikan dengan mengoptimalkan beberapa sumber saluran sejumlah media baik itu media cetak maupun media 
elektronik. Maksud dari tujuan pemasaran itu sendiri ada tiga yaitu pertama agar terjadi perubahan pengetahuan positif masyarakat terhadap lembaga tersebut, kedua perubahan sikap yang baik terhadap lembaga tersebut, dan ketiga perubahan tindakan yang dikehendaki dari perilaku masyarakat tentang lembaga pendidikan tersebut (Soemanagara, 2006: 4). Tidak dipungkiri lagi bahwa sekolah sebagai lembaga yang menawarkan produk kepada pengguna (konsumen) hendaknya selalu dengan sigap melayani masyarakat (peserta didik, mahasiswa) yang di kenal dengan istilah "stakeholder" yang bertujuan agar pihak yang dilayani tersebut mendapatkan kepuasan, dengan alasan mereka sebagai konsumen sudah membayar sebagai konsekwensinya.

Sedangkan pengertian jasa bisa disebut sebagai service yang memiliki beberapa makna, mulai dari makna pelayanan sesuatu ke seseorang yang dikehendaki, sampai bisa bermakna sebuah produk yang dihasilkan untuk kepentingan konsumen. Adapun makna jasa itu sendiri menurut beberapa ahli di antaranya Lovelock dapat diasumsukan ke dalam tiga hal sebagai berikut: Pertama, suatu proses kegiatan pendayagunaan sumber daya yang ada dari kelompok tertentu yang menghasilkan produk kemudian ditawarkan kepada kelompok yang lain. Kedua, suatu proses kegiatan aktifitas yang bersipat ekonomi yang dilakukan oleh kelompok tertentu dalam rangka menciptakan nilai serta manfaat bagi konsumen pada waktu dan tempat yang telah ditentukan. Ketiga, sesuatu proses kegiatan yang menghasilkan produk untuk konsumen dengan tujuan untuk di beli atau bisa di jual ke pelanggan (David Wijaya, 2016: 1).

Sebagaimana yang dikatakan oleh Kotler (2003: 428) dalam buku Pengolahan Pendidikan yang dikarang oleh Arah Hidayat dan Imam Machali, menjelaskan tentang kata jasa sebagai setiap produk perbuatan atau kinerja yang dipromosikan oleh suatu pihak pada pihak yang lainnya yang saling menguntungkan, jasa pendidikan yang ditawarkan oleh lembaga pendidikan biasanya mempunyai beberapa prinsip salah satunya adalah tidak berwujud/terlihat selain itu tidak menyebabkan kepindahan kepemilikan dari satu pihak ke pihak lain. Adapun karakteristik jasa pendidikan yang dikeluarkan oleh lembaga pendidikan adalah di antaranya: 1) Tidak berwujud/terlihat (intangible) oleh panca indra, sehingga yang terjadi adalah konsumen tidak dapat melihat, mencium, meraba, bahkan mendengar, dan 
merasakan sebelum mereka menggunakan jasa tersebut; 2) Tidak terpisahkan (inseparability) antara yang satu dengan yang lain, maksudnya adalah jasa tidak dapat dipisahkan dari sumbernya dan juga tidak dipisahkan dengan konsumen karena tujuan dari jasa pendidikan itu sendiri adalah untuk memenuhi kebutuhan masyarakat sebagai pengguna; 3) Bervariasi (variability) atau banyak macam, jenis dan sering berubah-rubah, maksudnya adalah jasa pendidikan sering kali berubah-ubah tergantung siapa, kapan, dan dimana penyajiannya; 4) Sering mudah musnah (perishability) atau hilang, dapat didefinisikan yaitu dengan tidak dapat diperjualbelikan pada masa selanjutnya; 5) Jasa tidak dapat disimpan dan dikonsumsi pada saat dihasilkan, maksudnya dari tidak bisa disimpan adalah jasa pendidikan tersebut digunakan pada saat itu juga tidak bisa digunakan untuk masa yang akan datang, adapun maksud dari tidak bisa dikonsumsi adalah jasa pendidikan bukanlah produk yang berjenis makanan melainkan berupa skill, pengetahuan dan lain-lain; 6) Konsumen merupakan salahsatu bagian internal terpenting dari proses produksi jasa, karena konsumen adalah pengguna dari jasa yang telah ditawarkan; 7) Setiap orang atau apapun yang ikut berhubungan dengan konsumen mempunyai andil dalam memberikan peran; 8) Karyawan atau staff sebagai penghubung merupakan bagian terpenting dari proses produksi jasa, oleh sebab itu diharapkan dalam pengangkatan karyawan harus bisa dilihat dari kualifikasi dan kompetensinya, karena hal itu akan mempengaruhi mutu dari jasa pendidikan tersebut; dan 9) Kualitas pembuatan jasa tidak dapat diperbaiki (rehab) pada saat proses produksi karena produk di jasa terjadi secara real time (Ara Hidayat dan Imam Machali, 2012: 228-229).

Lockhart (2005) bahwa hal-hal yang dapat mendorong pemasaran jasa pendidikan terbagi dalam lima faktor, di antaranya: 1) Meningkatnya kompetisi (persaingan positif) yang ada; 2) Perubahan demografi; 3) Ketidak percayaan masyarakat terhadap sebagian lembaga pendidikan yang ada; 4) Penyelidikan media masa baik media elektronik maupun media cetak; dan 5) Keterbatasan sumber yang ada (David Wijaya, 2012: 2-3). Perlu disadari bahwa pemasaran jasa pendidikan bukan merupakan suatu program atau kegiatan bisnis yang dilakukan oleh lembaga pendidikan agar sekolah yang dikelola tersebut mendapat siswa sebanyakbanyaknya, tetapi melainkan merupakan tangungjawab semua pihak. Pada intinya 
dalam pemasaran jasa pendidiknan, lembaga pendidikan bertujuan untuk memuaskan konsumen sebagai pengguna. Kegiatan pendidikan merupakan kegiatan sirkulasi anatara pihak satu dengan beberapa pihak lain yang saling mempengaruhi dan berkelanjutan untuk mencapai tujuan yang telah ditentukan. Karenanya harus memiliki langkah pembelajaran yang berdasarkan teori-teori tertentu (Sarifundin, 2018: 101).

Realita pasar yang sangat beragam karakternya itu perlu disiapkan atributatribut apa saja untuk memenuhi kebutuhkan masyarakat sebagai pengguna pendidikan agar apa yang dinginkan tercapai dengan baik. Pasar sebagai tempat menawarkan produk jasa pendidikan, dalam pedapat dibagi berdasarkan sebagai beriku: Pertama, berdasarkan demografi seperti usia, jenis kelamin, penghasilan, agama, dan lain-lainnya; kedua berdasarkan geografi yaitu berdasarkan wilayah seperti negara, kota atau komplek perumahan, dan lain-lainnya; ketiga berdasarkan psikografi seperti berdasarkan kelas sosial, gaya hidup, kepribadian, dan lain-lainnya; dan keempat berdasarkan perilaku (kesempatan, manfaat yang dicari, tingkat pemakaian, status loyalitas (Nugroho J. Setiadi, 2003: 61-63).

Kegiatan inti pemasaran jasa pendidikan, yaitu adalah adanya strategi bauran pemasaran. Dalam bauran tersebut terdapat unsur-unsur yang harus saling mendukung antara satu dengan yang lainnya. Jika ke semua unsur tersebut dipadukan akan menciptakan strategi pemasaran yang jitu efektif dalam merebut hati pengguna dan pada akhirnya memenangkan persaingan yang ada. Terdapat tujuh prinsip dalam bauran pemasaran, yaitu:

\section{Product (produk)}

Bahwa produk adalah segalah sesuatu yang ditawarkan oleh produsen ke pasar yang bertujuan untuk memenuhi kebutuhan dan keinginan masayarakat, atau dengan kata lain adalah memberikan sejumlah nilai kepada konsumen dalam hal memenuhi kebutuhannya. Adapun maksud dari produk bila dilihat dari kontek jasa pendidikan adalah berupa jasa yang ditawarkan oleh lembaga pendidikan ke masyarakat dalam hal ini adalah pelanggan. Hal yang ditawarkan adalah berupa reputasi, prospek, dan variasi pilihan. Suatu lembaga pendidikan sebagai yang mengeluarkan produk dapat menawarkan reputasi, prospek, mutu pendidikan yang baik, prospek, dan peluang yang cerah bagi para peserta didik untuk menentukan pilihan-pilihan yang diinginkannya demi keberhasilan di masa yang akan datang. Dalam hal ini lembaga pendidikan harus bisa 
menghasilkan kompetensi lulusan, yaitu kualifikasi dari kemampuan lulusan dari lembaga pendidikan tersebut yang mencangkup sikap (afektif), pengetahuan (pedagogik), dan keterampilan (skill).

\section{Price (harga)}

Maksud dari penjelasan price (harga) yaitu sejumlah kewajiban uang yang harus ditunaikan oleh konsumen atau pengguna untuk mendapatkan suatu produk yang diinginkan. Price dalam konteks ini adalah seluruh biaya pengeluaran dari pengguna untuk mendapatkan jasa pendidikan yang diinginkan. Adapun contoh-contoh price itu sendidri seperti uang bangunan, SPP, dan jenis pembayaran lainnya.

\section{Place (lokasi)}

Berarti lokasi atau tempat keberadaan lembaga pendidikan dalam menyelenggarakan aktifitas pendidikan. Dalam hal ini diharapkan lokasi atau tempat penyelenggaraan pendidikan berada di wilayah yang mudah diakses oleh pengguna jasa pendidikan. Selain itu, berada di wilayah yang strategis, nyaman, dan mudah dijangkau dari penjuru manapun.

\section{Promotion (promosi)}

Maksudnya adalah suatu kegiatan yang dilakukan oleh lembaga pendidikan dalam hal mengkomunikasikan atau menawarkan penjualan produk berupa jasa pendidikan yang berhubungan langsung dengan masyarakat sebagai pengguna. Tujuan dari promosi itu sendiri adalah untuk menyampaikan informasi yang jelas kepada masayarakat berkaitan dengan produk jasa pendidikan yang ditawarkan, dalam penyampaian diharapkan bisa meyakinkan konsumen atau pengguna akan keunggulan jasa pendidikan yang ditawarkan. Dalam melakukan kegiatan ini sebuah lembaga pendidikan biasanya mempromosikan lembaganya lewat media elektronik, media cetak, dan media-media lainnya.

5. People (orang)

Orang dalam konteks pengolahan manajemen pemasaran jasa pendidikan dapat diartikan sebagai sumber daya manusia (karyawan) yang terlibat secara langsung seperti tenaga pendidik (guru) maupun tenaga kependidikan seperti staf admnistrasi dan karyawan-karyawan lainnya. Pemilihan sumber daya manusia ini sangatlah urgen karena bisa berdampak terhadap keberhasilan tujuan dari pendidikan tersebut. Oleh sebab itu, dalam pengolahan sumberdaya manusia hendaknya dijalankan secara profesional berdasarkan kualifikasi dan kompetensinya. 


\section{Physical Evendece (bukti fisik)}

Adalah bukti adanya lingkungan fisik tempat jasa pendidikan itu dalam mengelolah lembaga pendidikan yang secara langsung penyelenggaraan berhubungan dengan konsumennya. Dalam hal ini ada dua macam katagori bukti fisik yaitu, pertama adalah berupa keberadaan gedung atau bangunan sekolah, kelas, gedung perpustakaan, lapangan olahraga, ruangan-ruangan, dan lain-lain. Adapun yang kedua adalah berupa bukti yang bersifat pendukung dalam proses penyelenggaran pendidikan atau bisa disebut sebagai nilai tambah dan memiliki peran yang sangat penting dalam proses jasa pendidikan seperti nilai rapot, catatan-catatan peserta didik, dan lain-lain.

\section{Process (proses)}

Maksudnya adalah prosedur atau mekanisme yang harus dilakukan dalam rangkaian kegiatan aktivitas untuk menyampaikan jasa yang diciptakan dari produsen ke konsumen atau pengguna. Dalam konteks jasa pendidikan proses adalah proses pendidikan yang mendukung terselenggaranya proses kegiatan belajar mengajar guna terealisasinya tujuan produk dalam hal ini adalah lulusan yang diinginkan oleh lembaga (Arah Hidayat dan Imam Machali, 2012: 238-241).
Begitu pentingnya pengolahan manajemen pemasaran jasa pendidikan, maka perlu dibuatkan langakah-langkah yang strategis dalam pemasaran jasa pendidikan khususnya di lembaga pendidikan yang bercirikan Islam, di antaranya adalah: pertama identifikasi pasar, maksudnya adalah suatu proses pengidentifikasian dan kegiatan menganalis keadaan pasar dalam hal ini masyarakat sebagai pengguna, sehingga lembaga pendidikan dapat mengetahui keadaan kondisi dan ekspektasi (kebutuhan-kebutuhan) pasar termasuk di dalamnya adalah berupa atribut-atribut pendidikan yang menjadi kepentingan dan kebutuhan konsumen pendidikan. Dalam hal ini sekolah Islam dinyatakan memiliki potensi yang cukup tinggi dalam upaya ikut serta mencerdaskan kehidupan bangsa dan mensukseskan program pemerintah berupa kegaiatan wajib belajar nasioanal yang telah dicanangkan.

\section{Segmentasi pasar dan kegiatan Positioning}

Segmentasi pasar maksudnya adalah kegiatan membagi suatu pasar menjadi kelompok-kelompok pembeli yang dibedakan menjadi kelompok pembeli yang memiliki karakteristik, atau memiliki tingkah laku yang biasanya pembeli tersebut membutuhkan produk yang berbeda-beda antara satu dengan 
yang lainnya. Sedangkan yang dimaksud dengan positioning adalah suatu kegiatan merancang suatu produk agar dapat selalu diingat oleh pengguna dan agar mendapat kesan positif dari konsumen dalam hal ini adalah pengguna.

\section{Diferensiasi produk}

Kegiatan diferensiasi adalah suatu cara pembedaan produk atau jasa antara yang satu dengan yang lain, cara ini merupakan cara yang sangat efektif suatu lembaga pendidikan dalam mencari perhatian pasar. Kegiatan ini pada intinya bertujuan untuk membuat menarik dari konsumen dari produk yang ditawarkan. Diferensiasi merupakan salah satu dari tiga strategi pemasaran jasa pendidikan sebagai strategi bersaing, karena: a) Diferensiasi dapat melakukan kegiatan penawaran yang berbeda-beda dibandingkan penawaran dari competitor yang ada; b) Keunggulan biaya maksudnya adalah strategi mengefisienkan penghematan dari seluruh pengeluaran biaya produksi atau jasa sehingga bisa di jual lebih murah jika dibading dengan pesaing yang ada; c) Fokus, maksudnya adalah melakukan strategi pemasaran dalam menggarap satu target khusus; dan d) Komunikasi pemasaran antara pihak yang terkait.

\section{Pelayanan sekolah}

Pelayanan sekolah hendaknya bisa memuaskan kehendak konsumen sebagai pengguna jasa pendidikan. Kesenjangan yang sering terjadi adalah adanya perbedaan persepsi kualitas maupun artibut pendidikan. Adapun ciri-ciri organisasi jasa yang baik: a) Memiliki konsep yang jelas yaitu fokus pada konsumen yang ada; b) Selalu berkomitmen terhadap kualitas dari managemen puncak; c) Perlu adanya penetapan standar yang tinggi dalam hal jasa pendidikan; d) Perlu adanya sistem yang bertugas untuk memonitor kinerja jasa pendidikan; e) Perlu adanya suatu sistem agar memuaskan keluhan pelanggan jasa pendidikan; dan f) Memuaskan para karyawan yang ada pada lembaga pendidikan tersebut sama puasnya dengan pelanggan jasa pendidikan (Arah Hidayat dan Imam Machali, 2012: 243-247)

Citra atau dalam bahasa Inggrisnya "image" memiliki pengertian sebagai impresi perasaan (sikap) atau konsepsi seseorang yang ada pada publik (masyarakat) mengenai perusahaan, mengenai suatu obyek, orang atau bahkan mengenai lembaga tertentu. Citra yang timbul tidak dapat dicetak atau dibuat seperti memproduksi barang-barang, melainkan dapat dihadirkan dengan cara dengan memberikan kesan yang diperoleh sesuai dengan pengetahuan, pemahaman sesorang pada sesuatu yang dialaminya. 
(Alma, 2003: 92). Kotler (1982:57) mengartikan image sebagai "..is the sum of beliefs, ideas, and impressions that aperson has an object".

Untuk dapat menarik perhatian publik, maka perlu dengan cara pembentukan image (citra) yang baik terhadap lembaga pendidikan (sekolah/madrasah), baik bisa berbentuk penyediaan sarana prasarana seperti bangunan fisik maupun daya tarik pengelolaan kegiatan-kegiatan yang besifat akademik, kegiatan keagamaan, dan kegiatan lainnya, di antaranya sebagai berikut: 1) Merenovasi bangunanbangunan sekolah agar bisa menarik perhatian masyarakat dalam mengenal lebih dalam MAT Darul Fallah Bogor; 2) Mengadakan dan mengoprasikan perlengkapan dan peralatan yang ada agar dapat berguna bagi masyarakat dan akhirnya masyarakatpun mengetahui betul keberadaan lembaga tersebut; 3) Bekerjasama dengan media elektronik, cetak dan media-media lainya; 4) Seorang kepala sekolah/madrasah hendaknya selalu gencar mengadakan pidato-pidato resmi, menghadiri pertemuan-pertemuan ilmiah, dan menginformasikan lembaganya ke masyarakat dengan baik; 5) Hendaknya aktif dalam memberikan konsultan (bimbingan) dan nasehat-nasehat yang diperlukan sebagai layanan masyarakat; dan yang 6) Berperan aktif dalam mengadakan peringatan hari-hari besar keagamaan misalnya PHBI; isro' mi'roj, maulud nabi, tahun baru Islam, dan lainlain (Arah Hidayat dan Imam Machali, 2012: 248-249).

\section{METODOLOGI PENELITIAN}

Dalam penelitian yang berlokasi di MAT Darul Fallah Bogor yang terletak di daerah Kabupaten Bogor, tepatnya di Jalan Raya Bogor-Ciampea KM 12 Bogor 16620, peneliti menggunakan metode pendekatan kualitatif deskriptif. Sekolah ini sebagai sebuah lembaga pendidikan setingkat menengah atas yang bercirikan Islam, kemandiran, dan kewirausahaan, yang berada di bawah naungan Yayasan Pesantren Pertanian Darul Fallah. Dalam penelitian ini, sumber data primer dari penelitian ini adalah berasal dari wawancara dengan pihak-pihak terkait seperti kepala sekolah dan dewan guru MAT Darul Fallah Bogor. Sedangkan data sekunder ialah sumber yang mendukung serta hubungan penelitian yang dibahas dimana sumber data sekunder dalam penelitian ini di antaranya bersumber dari buku-buku, dokumentasi, dan kepustakaan sumbersumber lainnya yang mendukung serta berkaitan dengan masalah dalam 
penelitian tersebut. Selain wawancara, dalam penelitian ini peneliti mengumpulkan data dengan menggunakan kegiatan observasi dan studi dokumentasi yang semua data-data tersebut berasal dari pengamatan secara langsung.

\section{IMPLEMENTASI BAURAN PEMASARAN JASA PENDIDIAN DI MAT DARUL FALLAH BOGOR}

Penelitian ini dilaksanakan pada bulan Maret sampai Juni 2019. MAT Darul Fallah Bogor merupakan lembaga pendidikan tingkat menengah atas dengan slogan "Dari Kampung Kembali ke Kampung”, berada di bawah naungan sebuah yayasan yang bernama Yayasan Pesantren Pertanian Darul Fallah.

\section{Strategi Bauran Pemasaran di MAT Darul Fallah Bogor}

1. Strategi Product

MAT Darul Fallah Bogor sebagai lembaga pendidikan menawarkan kepada masyarakat sebagai penguna jasa pendidikan yaitu sebagaimana tertuang dalam visi misi MAT Darul Fallah Bogor sebagai berikut "Terwujudnya madrasah unggul yang mampu menghasilkan peserta didik yang beriman, bertakwa, cerdas, mandiri serta mempunyai wawasan lingkungan yang baik," sesuai dinamika global dengan tetap peduli lingkungan dan berwawasan kebangsaan, melalui pelayanan prima, trasparan, dan akuntabel. Program yang ditawarkan pun memiliki dua varian yakni program relguler akademik dan juga program penguatan IMTAQ.

MAT Darul Fallah yang sudah berdiri sejak lama yaitu pada tahun 1960 sudah banyak mencetak alumni-alumni yang berkualitas dan memberikan kepercayaan bagi konsumen pendidikan yang inginkan anaknya setelah lulus dari sekolah memiliki akhlak, agama, dan kemampuan akedemik dan non akademik yang sangat baik. Sebagai sekolah swasta yang memiliki mutu pendidikan yang sangat baik karena para siswanya dibekali jiwa kewirausahaan dan kemandiriaan.

Sekolah ini pula sudah terkenal hampir di seluruh Indonesia, hal ini dibuktikan dengan asal siswa-siswinya selain berasal Jakarta, Bogor, Depok, Tangerang, dan Bekasi (JABODETABEK), juga banyak siswa-siswa yang berasal dari wilayahwilayah yang ada di Indonesia seperti berasal dari Aceh, Sumatra Utara, Riau, Jambi, Sumatera Selatan, Sumatera Barat, Bengkulu, Lampung, Jawa Tengah, Daerah Istimewah Yogyakarta (DIY), Maluku, Nusa Tenggarah Barat, Nusa Tenggarah Timur, Bali, Irian, Kalimantan Barat, Kalimantan Selatan, Kalimantan Tengah, Kalimantan Timur, Sulawesi 
Selatan, Sulawesi Tengah, Sulawesi Timur,Gorontalo, Sulawesi Utara, Maluku, dan provinsi-provinsi lainnya.

Sedangkan prospek siswa MAT Darul Fallah adalah para alumninya dapat bersaing dengan siswa lain yang dan dapat menjadikan manusia yang beragama, dan yang paling diutamakan adalah membentuk siswa yang berjiwa kemandirian dan berjiwa kewirausahaan dalam bidang pertanian, perikanan dan pertenakan.

\section{Strategi Price}

Strategi price yang dilakukan di MAT Darul Fallah suda baik. Hal ini dibuktikan dengan banyaknya pada pendaftar yang ingin sekolah di MAT Darul Fallah Bogor. Biaya pendidikan di MAT Darul Fallah Bogor terjangkau di antaranya uang masuk sebesar 11.000.000,- dan biaya perbulan sebesar 750.000,-. Adapun untuk pembiayaan sekolah MAT Darul Fallah selain dari para orang tua siswa, MAT Darul Fallah Bogor juga selama ini mencarikan beasiswa bagi siswa yang kurang mampu dan berprestasi yaitu dengan berkerjasama dengan Dewan Dakwah Islamiyah Indonesia (DDII), dan Badan Amil Zakat Nasional (BAZNAS).

\section{Strategi Place}

Luas tanah yang dimiliki oleh MAT Darul Fallah ini luas yaitu 26,5 hektar, yang berlokasi tidak jauh dengan salah satu perguruan tinggi nasional ternama di Indonesia yaitu Institut Pertania Bogor (IPB) dan tidak jauh dari pusat kota dengan akses jalan yang sangat ramah dan mudah untuk dijangkau. Di lokasi tersebut dengan fasilitas area lahan sekolah dan gedung yang luas dan suasana sejuk dan asri di sekolah ini yang memiliki banyak pohon rindang sebagai asupan oksigen sehat bagi para masyarakat sekolah. Tentunya dengan suasana yang sejuk dan asri membuat konsentrasi belajar siswa sangat baik dengan suasana ramah dan yaman ini siswa akan mudah memahami materi pelajaran yang diberikan kepada mereka. Meskipun berada di pusat kota yang lumayan panas, ketika sudah berada di sekolah ini kesejukan akan menyambut, menjadi modal lokasi yang sangat baik bagi sekolah MAT Darul Fallah Bogor ini.

\section{Strategi Promotion}

Ada beberapa strategi promosi yang secara umum yang digunakan oleh MAT Darul Fallah dalam jasa pendidikan, yaitu strategi pemasaran dengan berkerjasama dengan beberapa lembaga dalam perekrutan siswa baru seperti dengan Dewan Dakwah Islamiyah Indonesia (DDI) dan Badan Zakat Nasional (BAZNAS). Selain itu, MAT Darul Fallah mengoptimalkan peran alumni 
yaitu dengan dibentuknya Ikatan Alumni MAT Darul Fallah. Organisasi ini diharapkan berperan aktif dalam perekrutan siswa baru. Strategi kekeluargaan ikatan alumni adalah strategi pemasaran sekolah yang dibantu oleh para alumni yang sudah menjadi bagian dari keluarga besar sekolah ini. Dengan kuatnya ikatan alumni mereka dapat mempromosikan sekolahnya kepada kelurga, teman, dan halayak ramai lainya. Dengan begitu promosi ini lebih bersumber dari testimoni alumni yang sudah pernah merasakan pelayanan kualitas sekolah ini. Selain itu, strategi berbasis Teknologi Elektronik mengikuti perkembangan zaman dengan semakin banyaknya media sosial penghubung manusia lain yang mudah, murah, dan cepat, maka MAT Darul Fallah menggunakan sosial media sebagai sarana promosi sekolah mulai dari, facebook, instagram, youtoobe, dan sebagainya hingga penyiaran lewat radio. Dengan begini promosi seperti ini akan semakin luas dan efektif dari segi waktu dan dana.

\section{Stategi People}

Dalam melaksanakan kegiatan pendidikan di MAT Darul Fallah Bogor didukung oleh tenaga pendidik dan tenaga kependidikan yang sesuai kompetensi dan kualifikasinya. Hal ini dibuktikan dengan semua tenaga pengajar berpendidikan
Strata Satu (S1), ada pula yang berpendidikan Strata Dua (S2) dan Strata Tiga (S3). Begitu pula dengan tenaga kependidikan yang mayoritas berpendidikan Strata Satu (S1). Untuk meningkatkan kualitas kompetensi pelayanan pendidikan manajemen, MAT Darul Fallah Bogor selalu mendorang para karyawanya untuk mengikuti kegiatan-kegiatan yang bersifat positif dan menunjang kompetensi, seperti pelatihan, seminar, workshop, dan kegiatan-kegiatan lainnya.

\section{Strategi Physical evidance}

Selain memiliki luas tanah yang sangat luas yaitu 26,5 hektar, MAT Darul Fallah juga memiliki bukti fisik yang ditampilkan. MAT Darul Fallah memiliki fasilitas sekolah yang baik dan terawat dan mampu mencukupi kebutuhan para siswanya, fasilitasnya antara lain, masjid dengan kapasitas 1000 orang, laboratorim MIPA, laboratorium komputer, ruang ujian berbasis komputer (UNBK), laboratorium bahasa, ruang audio visual, perpustakaan, lapangan sekolah, gedung olahraga, ruang UKS, ruang-ruang praktikum, dan ruang-ruang lainnya.

\section{Strategi Process}

Dari aspek kurikulum, MAT Darul Fallah mengikuti standar yang telah ditetapkan oleh kementerian Pendidikan Nasional. Hal ini dapat terlihat dari muatan mata 
pelajaran maupun kegiatan yang dilakukan di sekolah ini. Selain itu, kurikulum MAT Darul Fallah itu sendiri yaitu Kewirausahaan dan Kemandiriaan dimana kedua kurikulum tersebut merupakan ciri khas dari MAT Darul Fallah. Kegiatan pembelajaran dilakukan secara integrasi dan juga belajar langsung dari muatan belajar praktikum. Pelajaran yang di tanamkan setiap hari dengan adanya kelas khusus menghafal dan membaca Alquran dengan baik dan benar. Setiap keluhan, usulan, dan aspirasi yang disampaikan oleh para wali murid ditampung dengan baik dan dibicarakan secara formal dan bersifat kekeluargaan.

\section{KESIMPULAN}

Dari penelitian di atas dapat disimpulkan bahwa implementasi bauran pemasaran pendidikan di MAT Darul Fallah Bogor adalah sebagai berikut: Pertama, dari strategi produk yang ditawarkan oleh sekolah MAT Darul Fallah Bogor kepada pelanggan secara global dapat direalisasikan dalam visi sekolah tersebut yakni "Terwujudnya madrasah unggul yang mampu menghasilkan peserta didik yang beriman, bertakwa, cerdas, mandiri serta mempunyai wawasan lingkungan yang baik." Program yang ditawarkan MAT Darul Fallah adalah kepada para peserta didik agar memiliki mutu pendidikan yang baik karena selain dibekali supaya menjadi manusia yang beragama juga dibentuk menjadi pribadi yang berjiwa kemandirian dan kewirausahaan dalam bidang pertanian, perikanan dan pertenakan.

Kedua, strategi price, biaya pendidikan di MAT Darul Fallah Bogor sangat terjangkau di antaranya uang masuk sebesar 11.000.000,- dan biaya perbulan sebesar 750.000,- suda termasuk SPP dan makan tiga kali. Adapun sumber pembiayaan MAT Darul Fallah Bogor yang lainnya berasal dari programprogram kerjasama beasiswa bagi siswa yang kurang mampu namun berprestasi yaitu dengan berkerjasama dengan Dewan Dakwah Islamiyah Indonesia (DDII), Badan Amil Zakat Nasional (BAZNAS), dan beasiswa-beasiswa lainnya.

Ketiga, strategi place adalah luas tanah yang dimiliki oleh MAT Darul Fallah Bogor sangatlah luas yaitu 26,5 hektar, berada di lokasi tidak jauh dari pusat kota dengan akses jalan yang mudah untuk di jangkau. MAT Darul Fallah Bogor memiliki fasilitas area lahan parkir dan gedung yang luas dan suasana sejuk dan asri karena di sekelingnya banyak pepohonan yang rindang 
Keempat, strategi promosi MAT Darul Fallah Bogor yaitu yaitu melalui media sosial, alumni yang tersebar di seluruh Indonesia. Selain itu berkerjasama dengan beberapa lembaga dalam perekrutan siswa baru seperti dengan Dewan Dakwah Islamiyah Indonesia (DDII), Badan Amil Zakat Nasional (BAZNAS).

Kelima, stategi People, yaitu dengan merekrut tenaga pendidik dan tenaga kependidikan yang sesuai kompetensi dan kualifikasinya yaitu mayoritas karyawan berpendidikan minimal Strata Satu (S1). Selain itu pihak MAT Darul Fallah Bogor mendorong para karyawannya untuk meningkatkan kompetensi dan kualifikasi yaitu dengan melanjutkan pendidikan ke jenjang yang lebih tinggi dan mengikuti kegiatan-kegiatan pengembangan diri, seperti pelatihan, seminar, workshop, dan kegiatan-kegiatan lainnya.

Keenam, strategi Physical Evidance, MAT Darul Fallah Bogor memiliki fasilitas yang lengkap, seperti Masjid dengan kapasitas 1000 orang, laboratorim MIPA, laboratorium komputer, ruang ujian berbasis komputer (UNBK), laboratorium bahasa, ruang audio visual, perpustakaan, lapangan sekolah, gedung olahraga, ruang UKS, ruang praktikum dan lain-lain.
Ketujuh, strategi Process, dari aspek kurikulum, sekolah MAT Darul Fallah Bogor mengikuti standar yang telah ditetapkan oleh kementerian Pendidikan Nasional dan ditambah dengan kurikulum Kewirausahaan dan Kemandirian. Kegiatan pembelajaran dilakukan secara integrasi dan juga belajar langsung dari muatan belajar praktikum. Pelajaran yang ditanamkan pada siswa bertujuan untuk menumbuhkan rasa kemandirian dan kewirausahaan. Proses belajar mengajar bersifat kekeluargaan.

Begitu pentingnya pemasaran jasa pendidikan, maka peneliti menyarankan agar manajemen pengolahan dilaksanakan dengan profesional karena karena input pendidikan merupakan investasi masa depan yang sangat penting. Lembaga pendidikan dalam hal ini MAT darul Fallah Bogor hendaknya terus menerus meningkatkan mutu pendidikan, karena dengan peningkatan mutu yang ditawarkan akan berdampak pada kepuasan masyarakat sebagai pengguna sehingga bisa menjadi umpan balik lembaga pendidikan tersebut dalam memasarkan jasa pendidikan.

\section{DAFTAR PUSTAKA}

\section{Sumber dari Jurnal}

Kulsum, U., Sarifudin, dan Maya, R. (2019). Implementasi Manajemen Infrastruktur Pendidikan di SMP Islam HASMI Bogor. Proceeding. 
The $2^{\text {nd }}$ Annual Conference on Islamic Education Management: THE SCIENTIFIC PARADIGM OF ISLAMIC EDUCATION MANAGEMENT. Manado: ACLEM, PPMPI, IAIN MANADO, dan PERMA PENDIS INDONESIA.

Maya, R. (2016). Revitalisasi Keteladanan dalam Pendidikan Islam: Upaya Menjawab Peluang dan Tantangan Pendidikan Islam di Era Masyarakat Ekonomi ASEAN (MEA). Edukasi Islami: Jurnal Pendidikan Islam, 05(09).

Maya, R. (2017). Karakter (Adab) Guru dan Murid Perspektif Ibn Jamâ'ah AlSyâfi'î. Edukasi Islami: Jurnal Pendidikan Islam, 06(12).

Maya, R., dan Lesmana, I. (2018). Pemikiran Prof. Dr. Mujamil Qomar, S.Ag tentang Manajemen Pendidikan Islam. Islamic Management: Jurnal Manajemen Pendidikan Islam, 01(02)

Sarifudin. (2018). Manajemen Facebook dalam Proses Pembelajaran Pendidikan. Islamic Management: Jurnal Manajemen Pendidikan Islam, 01(01).

Sarifudin. (2019). Implementasi Supervisi Kepala Sekolah terhadap Kinerja Guru dalam upaya Meningkatkan Kualitas Pembelajaran. Islamic Management: Jurnal Manajemen Pendidikan Islam, 02(01).

\section{Sumber dari Buku}

Alma, B. (2005). Pemasaran Stratejik Jasa Pendidikan. Bandung: Alfabeta.

Alma, B. (2009). Manajemen Corporate dan Strategi Pemasaran Jasa Pendidikan Fokus pada Mutu dan Layanan Prima. Bandung: Alfabeta.

Alma, B. (2014). Manajemen Pemasaran dan Pemasaran Jasa. Bandung: Alfabeta.
Asmani, J.M. (2015). Manajemen Efektif Marketing Sekolah Pertama. Yogyakarta: Diva Press.

Haryati, Y. dan Muhsin, M. (2014). Manajemen Sumber Daya Pendidikan, Bandung: CV Pustaka Setia.

Hidayat, A dan Machali, I. (2012). Pengelolaan Pendidikan. Yogyakarta: Kaukaba.

Setiadi, J.N. (2003). Perilaku Konsumen: Konsep dan Implikasi untuk Strategi dan Penelitian Pemasaran, Jakarta: Prenada Media.

Mulyono. (2008). Manajemen Administrasi dan Organisasi Pendidikan, Yogyakarta: Ar-Ruzz Media.

Qomar, M. (2007). Manajemen Pendidikan Islam: Strategi Baru Pengelolaan Lembaga Pendidikan Islam, Jakarta: Erlangga.

Soemanagara. (2006). Strategic Marketing Communication: Konsep Strategi dan Terapan. Bandung: Alfabeta.

Sutisna. (2003). Perilaku Konsumen dan Komunikasi Pemasaran. Bandung: PT Remaja Rosdakarya.

Tim Dosen Administrasi Pendidikan UPI. (2011). Manajemen Pendidikan, Bandung: Alfabeta

Usman, H. (2006). Manajemen: Teori, Teknik, dan Riset Pendidikan. Jakarta: Bumi Aksara.

Wijaya, D. (2012). Pemasaran Jasa Pendidikan, Jakarta: Salemba Empat.

Wijaya, D. (2016). Pemasaran Jasa Pendidikan, Jakarta: PT Bumi Aksara. 
